13.2.5 その他 ロールについては新材質の開発 や性能についての報告(88) (92) がいくつかあり，王延 機本体について主駆動系の動特性の解析 ${ }^{(93)(94)}$, 軸受

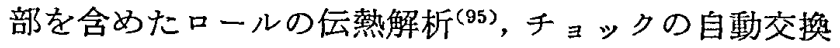
蔆置に関するもの ${ }^{(96)}$, 王延機モータの現状と将来の 展望 ${ }^{(97)}$ がある。この汸か，圧延工場の品質管理に関 する報告(98)(99)，鉄鋼業に和ける王延技術あるいは塑 性加工技術全般(100)(101) に関してその未来像について 展望がなされている、以上のほかに, 新しく発刊され た JMWT 誌に形鋼生延の屡望 ${ }^{(102)}$ ，円管の絞り压延 における王力分布の測定(103)，円管のプラネタリミル による校り圧延 ${ }^{(104)}$ の論文がある。【林千博]

\section{3 引拔き・押出し}

13·3・1 引技き 解析的研究としては引拔き材を ビンガム体とした粘塑性理論(105), 同心円状に多層に 構成された線の引拔き理論(106) があり，奏験的研究で は管の空引き(107)(108)及び心金引き(109)の際の肉厚分布 を調べたものが報告されている，線の特殊な製造方法 として高速度鋼を 400〜800 ${ }^{\circ} \mathrm{C}$ に予熱して引抜く実験 (110), 線の局部を加熱して引張り縮径加工を行らダイ レス引抜き(111)(112), 溶融金属から直接に金属線を作 り出す研究(113) (116)がある.

線の性質に関して鋼線の引坟き後の引張強さを炭素 含有量, 真ひずみから算出する害験式(117)(118), 含有 窒素と伸線条件が強度に及ぼす効果 ${ }^{(119)}$ ，ステンレス 鋼線の疲労強度に及ぼす組織と加工硬化の影響(120), 高温 Mo 線の高真中空での疲労強度(121)， $20^{\circ} \mathrm{C} \sim-$ $50^{\circ} \mathrm{C}$ に和ける高強度線の疲労強度(122), PC 鋼線(123) (124)，ステンレス鋼線(125) のリラクセーション值が調 ベられている. 線表面に人工的な欠陷を作って冷間王 造性を調べた研究がある(126).

引抜き仕事を測定し半理論的に摩擦俰数を求めた研 究(127)，板材を引抜くときの摩擦係数に及ぼすダイス 面圧，引技き速度，被膜厚さの影響が調べられている (128) (130)．りん酸亜鉛被膜の性能向上をはかったもの

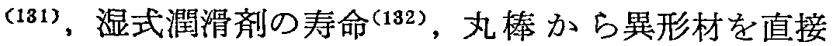
引拔く場合のダイス形状を最小仕事の原理から求めた もの (133), ダイス各部の形状決定とパススケシュール

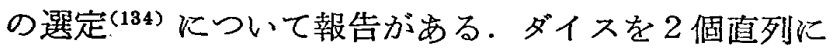
配置しその間に高圧潤滑剂を注入した压力ダイスによ る引抜さの研究(135) (138), 焼結ダイヤモンドダイスの 使用実績の報告(139) (141)がある.

超音波を引抜きに利用する技術に関しては，基礎的 な研究(142)，ダイスの加工 (143)，疲労試験機とそれに よる疲労試験(144)の研究がある.
溶融被膜金属中で心線を $10 〜 450 \mathrm{~m} / \mathrm{min}$ で引上げ て被膜を作る高速めっきが実験室規模で成功している (145). パテンティング設備の解説(146)(147), ロールペン ダディスケーラ用ロールの設計法(148), 各種の線, 線 材の熱処理の解説 ${ }^{(149)}$ がなされている.

本報告は日本塑性加工学会伸線技術分科会の情報委 員及び古堅・藤井（住金・中研）から提供された資料 に基づくものである。

[小川徹]

$13 \cdot 3 \cdot 2$ 押出し 押出しの理論面では流線を仮定 した前方押出しの解析 ${ }^{(150)}$, 有限要素法による応力解 析 ${ }^{(151)(152)}$, 管の押出し王力式(153), 丸棒の押出し王力 式(154)(155) について報告された。 CAD 手法によるダイ ス設計(156)(157), アルミ合金押出し時の温度上昇の解析 と温度の品質に及ぼす影響(158) (161) が検討され, 理論 解析結果が押出しプロセスの制御に活用されている.

間接押出しの非鉄金属に対する活用がめだって多く なったアルミ合金用間接押出しプレス設備 ${ }^{(162)}$ ， ス テム強度を高める方法 ${ }^{(163)}, 3600 \mathrm{t}$ プレスによる管押 出し例 ${ }^{(164)}$, 形材の間接押出 しの能率化 ${ }^{(165)}$, 潤滑剤 を用いた間接押出し(166)が報告され，またアルミ合金， 銅合金管の直接・間接押出乙を比較し, 生産性, 品質 面での間接法がすぐれていることが明らかにされた (167).

值接押出しに関しては大径耐熱鋼管の押出し(168), ラジアルェクストルージョン(169), クリーニングプレ 一トによるアルミ押出しの高速化 ${ }^{(170)}$ ，異形材押出し の押出し压(171) について検討された。

押出し材の品質に関し，アルミ押出し材の組織(172), 快削アルミ合金の押出し温度と切削性 ${ }^{(173)}, ア ル ミ$ 合 金の高温ねじり特性と押出し区の関係 ${ }^{(174)}$, 押出乙性 に対する添加元素およびビレット組織(175) (177)の影響 が明らかにされ，またアルミ押出しのピックアップ損 傷の発生機構 ${ }^{(178)}$, ステンレス鋼管押出しの表面すべ

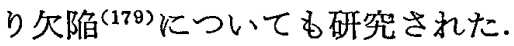

冷間静水匠押出しでは銅クラッドアルミ異形材(180) 和よび線材 ${ }^{(181)(182)}$ の押出しが行われたが，最近は高 温静水王押出しが広まりつつある. 高温静水王押出し

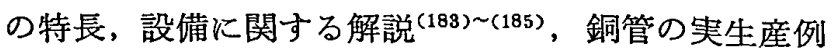
(186)，アルミ合金の高温静水纴押出し例(164)(187)の紹 介, 粘塑性圧力媒体を用いた非鉄材料の高温押出し (188)の報告があった。また茲材表面に液压を加えて押 出しの高速化に成功した例(189) ああった。

線材押出しはコンフォーム法が工業化されようとし ている．原理扣よび特長の解説(190) (192)，コンフォー ム法で製造されたアルミ線の品質調查 ${ }^{(198)}$, ニンフォ

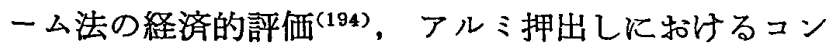


フォーム法とりネックス法の比較(195) またコンフォー ム法を改良したディスク押出し法 ${ }^{(196)}$ が報告された。 さらには液体の粘性力を利用した多段連続押出し(197) が研究された。

特殊な押出しでは鉄粉の熱間ガラス潤滑押出し(198)， スクラップ材の熱間押出し(199)(200), さらには溶湯押 出し(201) が報告され, 省資源, 省エネルギの押出し方 法が検討された。

押出し用設備に関しては押出し用プレスの発展史 (202), ビレットの誘導加熱法の検討 $^{(203)(204)}$, そして工 具に関してはアルミ合金の押出しを対象にした報告 (205)があった。

[松下 富春]

\section{$13 \cdot 4$ 冷 間 鍛 造}

13.4.1 基礎研究 材料的な面からは球状化や 粒径の影響(206)(207)が調べられ, 動的な条件での変形抵 抗の測定 ${ }^{(208)}$ がなされた汪か，延性破壞条件式が作 成された(209)(210), 解析に関しては押出し鉛造のすべり 線場の計算機による解法 ${ }^{(211)}$ や上界法による解法 ${ }^{(212)}$ があり, 岡塑性有限要菜法によって円柱の王縮 ${ }^{(213)}$ (214) や薄板の圧縮 ${ }^{(215)}$ が取扱われた。

13.4.2 冷間鍛造 冷間鍛造の解説 (216) や応用に 関する記事(217) があったほか, 冷䦜一熱間鍛造の組合 せ加工 (218) も行われた. 材質的な面からは残留応力の 研究(219) があり, 冷間鍛造性試験に関する研究(220) (224) 多かった.

力学的な面からは複合材の押出し(225), スエージ鍛 造(226), 半密閉鍜造(227) が研究された. 工具について は, 工具鋼のじん性に関する研究(228) (230) がなされ た。摩擦係数の测定にはリング圧縮法 ${ }^{(231)(232)}$ が用い

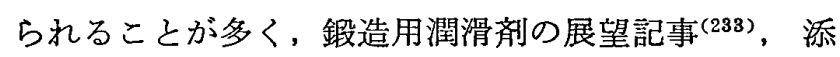
加剂を加えた液体潤滑剂の特性 ${ }^{(234)}$, 押出し鍛造製品 の表面状態に関する研究(285) があった。鍛造用につい てはへッダの設計に関する具体的な考え方が示された (236)ほか, 二重コラムプレス ${ }^{(237)}$, エキセンプレス ${ }^{(238),}$ 冷間押出しプレス (239) の剛性に関する研究が行われ た. EMO 2 に出品された多くのプレスが Indust. Anz. 誌に詳細に紹介されている.(240).

14.4・3 温間鍛造温間鍛造の広範な展望が行わ れ(241)，温間後方押出しの加工王力の国際協力研究成 果が発表された ${ }^{(242)}$. 温間鍛造材の再結晶 ${ }^{(243)}$, クラ ック (244)，延性や荷重 ${ }^{(245)}$ の研究がある. 軸受鋼の温 間鍛造 ${ }^{(246)}$, 温間鍛造の応用 ${ }^{(247)}$, 液生シリンダの加 工 ${ }^{(248)}$, 高強度ボルトの製造 ${ }^{(249)}$ ，秝じ状製品の加工 〔250)など、温間鍛造の応用も増加している。

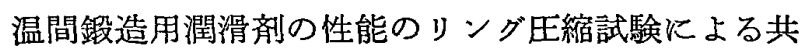

同研究がまとめられ(251). ダイス摩耗について論じら れ(252)，夷用的な潤滑剂が紹介された (253).

13.4.4 熱間鍛造国際型鍛造会議扣よび国際自 由鍜造会議が京都で開催され, それぞれ 22 件および 27 件の発表が行われた.

熱間鍛造の応用例としては，等温鍛造 ${ }^{(254)}$, タービ ン羽根の製造 ${ }^{(255)}$, 経済問題に関する記事 ${ }^{(256)}$ があっ た. 自動車用型鍛造品の 振動強度 (257)(258) やパック鍜 造品の性質 ${ }^{(259)}$ が論じられた. 解析としては, 熱間鍜 造の所要力の計算 ${ }^{(260)}$, 精密鍛造に打ける温度 ${ }^{(261)}$, かさ雨車の鍛造荷重 ${ }^{(262)}$, 金型の温度分布 ${ }^{(263)}$, 平面 ひずみ鍛造における流れ(264)などが取扱われた、工具 に関しては, 寿命(265), 熱応力 ${ }^{(266)(267)}$ 等が調べられ, 超硬合金金型 ${ }^{(268)}$ や金型製作に関する記事 ${ }^{(269)}$ があっ た. 熱間鍛造用潤滑剂(270)(271), 素材加熱(272)(273), 鍜 王機械 ${ }^{(274) \sim(277)}$ につての発表も多くあった。

13.4.5 その他の鉭造 回転鍛造については比較 的多くの研究がなされた (278) (281). 回転スエージング (282), WPM 法によるスプライ.ン加工 ${ }^{(283)}$, Fab-Forge による円盤外周のみぞ加工 (284), 鋳造と鍛造の複合加 工 ${ }^{(285)}$ ，噴射鍛造 ${ }^{(286)}$ などの紹介があった。

粉末鍛造に関しては多くの論文が出され(287) (292), 本法が実用に入りつつあることを示した，以上のほ か,タービン翼車の鍛造の超塑性材料によるモデル実 験 ${ }^{(293)}$ ，棒及び管の半径方向鍛造ダイスの設計 ${ }^{(294)} に$ ついての論文がある。

[小坂田宏造]

\section{5 板 材 加工}

13.5.1 世ん断加工 打技さ工具によるもので は，格子線観察法による材料挙動 (295)，愿板打抜さ荷 重の算出法 ${ }^{(296)}$, 摩耗・寿命に対する工具材質 ${ }^{(297)}$ 等, 細長比の大きいこと ${ }^{(288)}$ ，打技き速度(299) の各影響, 打技さ性の概念 ${ }^{(300)}$ が報告され、ファインブランキン グの進歩の実例(301)(302)，仕上げ抜きのポイント(303), シェービング法 ${ }^{(304)}$, 上下抜き法 ${ }^{(305)}$ の各改善方法, 対 向ダイス法の実例 ${ }^{(306)}$ ， ベイナイト積䁲簡易形(307) が 報告された，棒材のせん断では，すべり線場による变 形過程 ${ }^{(808)}$, 高速せん断の利点 ${ }^{(309)}$, 注意すべき点 ${ }^{(310)}$, 一般的解説 ${ }^{(311)}$ が報告され，その他スリッティング技 術に関する研究(312)(313), 一般的解説 ${ }^{(314)}$ も発表され

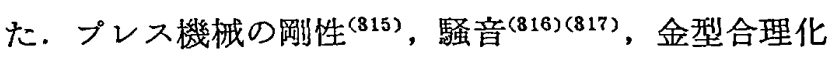
の指針 ${ }^{(318)(319)}$, 板取りに関する歩留り向上の手法 ${ }^{(320)}$ についても報告されだ.

[村川 正夫]

\subsection{2 成形加工}

a. 成形法, 成形装置, 型 プレス工業の 50 年 の歴史の解説 ${ }^{(321)}$ ，プレス機械の変遷と現況を紹介し 